\title{
Ohmic heating/vacuum impregnation treatments on osmodehydrated apples enriched in polyphenols from concentrated pomegranate juice
}

Moreno, J.; Zuñiga, P.; Guerra, M.E.; Mella, K.

TECBAL group. Department of Food Engineering, Universidad del Bio-Bio, Chillán, Chile.

*E-mail of the corresponding author: jomoreno@ubiobio.cl

\begin{abstract}
The aim of this work was to study the combination of osmodehydration (OD), coupled with Ohmic Heating (OH) and Pulsed Vacuum (PV) and to introduce natural compounds from a cryoconcentrated pomegranate juice $\left(47^{\circ} \mathrm{Brix}\right)$ at 30, 40 and $50{ }^{\circ} \mathrm{C}$ into apple matrix, during $180 \mathrm{~min}$. $P V$ was performed at 50 mbar for 5 min at the beginning of the process and $\mathrm{OH}$ generates an electric field of $6.6 \mathrm{~V} / \mathrm{cm}$. The results indicated that treatments reduced water content and increase polyphenol content of apples, evidencing that the osmotic treatment improve mass transfer, especially when they are applied together at higher temperatures.
\end{abstract}

Keywords: Ohmic heating; pulsed vacuum; cryoconcentration; enriched; pomegranate. 


\section{Introduction}

As consequences in a change of lifestyle and eating habits diseases such as obesity, cardiovascular problems, diabetes type II, hypertension, cancer among others have increased (1). These adverse effects have developed the interest in healthy food and the consumption food functional food (2). Functional foods include bioactive compounds (BAC), which have health benefits as well as their nutritional value. Vitamins, polyphenols, and minerals are found in BAC (2).

Pomegranate (Punica granatum L.) has gain interest in the past few years for its nutritional and antioxidant activities (3). Pomegranate juice is a potential source of anthocyanins, flavonoids, organic acids, ellagic acid (4). Therefore, its health benefits are associated with those chemical characteristics. Therefore, its health benefits are associated with those chemical characteristics.

Freeze concentration (also called cryoconcentration) as mention before, is an emerging technology, which consists on entirely or partially freezing the liquid food solution for later separation of the ice fraction from the liquid. Vitamins as polyphenols are thermolabile compounds, by using FC the high nutritional value and organoleptic characteristics can be protected (5).

The ohmic heating $(\mathrm{OH})$ is a thermal process, in which energy is generated by the passage of an alternating electrical current that diffuses through the food (2). The PV has been widely used to obtain a rapid penetration of compounds in vegetable tissues and enriches fruits and vegetables with antioxidants, vitamins, minerals, among others (6).

Osmotic dehydration (OD) is the process in which water is partially removed from the cellular material when it is exposed to a concentrated solution of solutes. The type of osmotic agent used and its molecular weight or ionic behavior affects the kinetics of water elimination and the gain of solids (7), during the OD mass transfer occurs through semipermeable cell membrane making substantial changes in the tissue structure (8).

The aim of this work was to study the combination of osmodehydration (OD), Pulsed Vacuum (PV), Ohmic Heating $(\mathrm{OH})$ and to introduce natural compounds from a concentrated pomegranate juice at 30,40 and $50{ }^{\circ} \mathrm{C}$ into an apple matrix, during 180 minutes.

\section{Materials and Methods}

\subsection{Sample preparation}

Pomegranate (cv. Wonderful) and apples (cv. Granny Smith) were acquired in the local market (Chillán, Chile) and stored under refrigeration $\left(5^{\circ} \mathrm{C}\right)$ until processing. The 


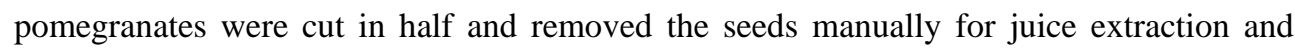

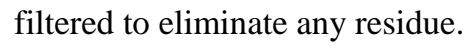

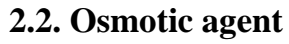

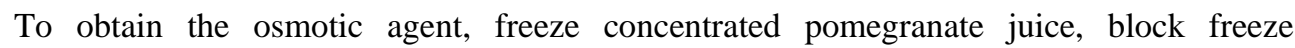

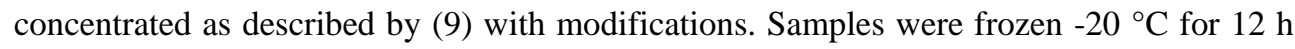

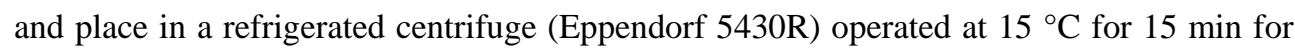

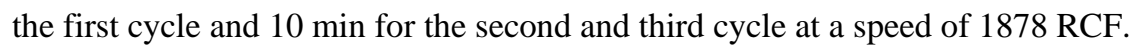

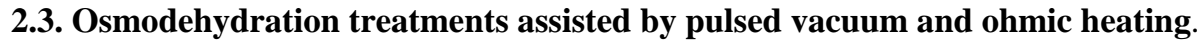

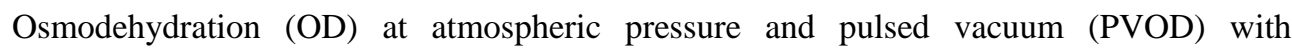

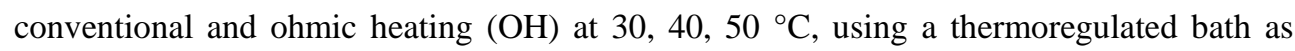

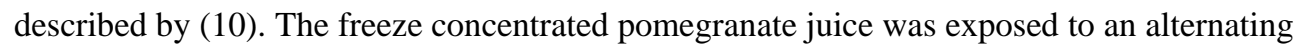

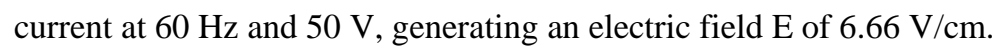

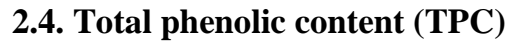

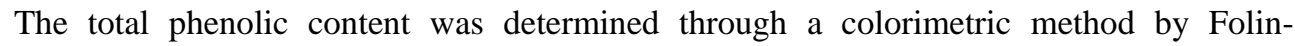

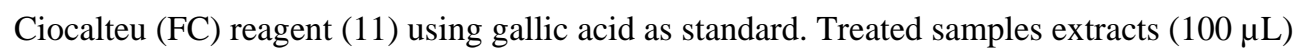

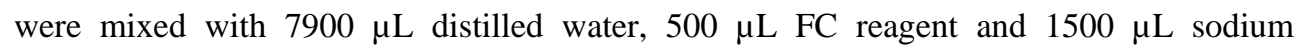

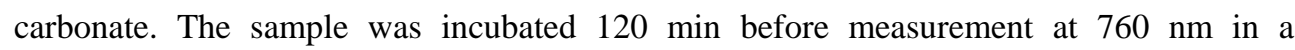

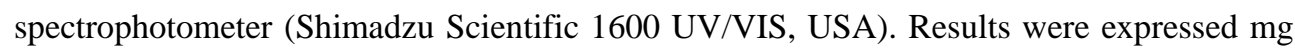

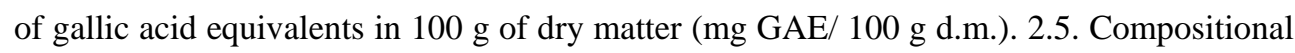

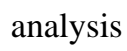

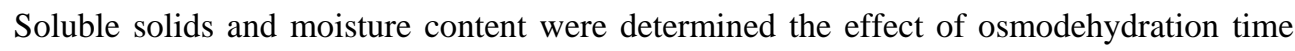

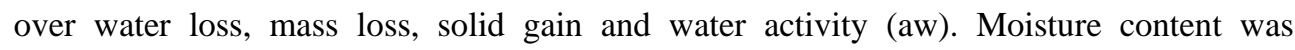

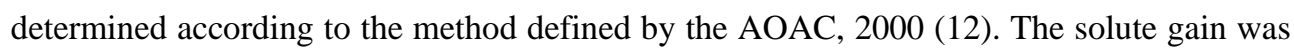

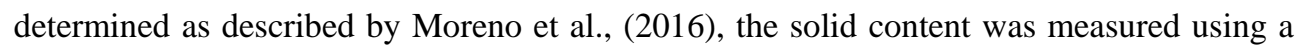

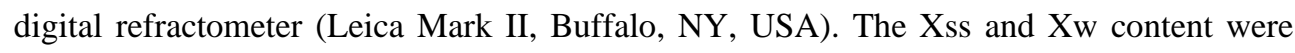

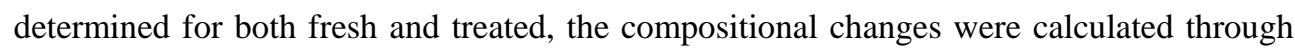

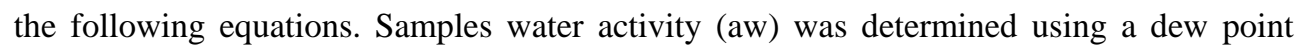

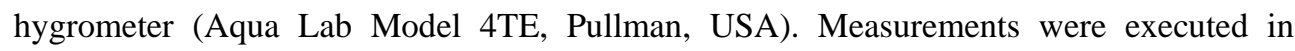

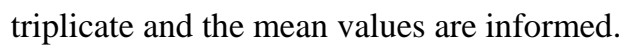

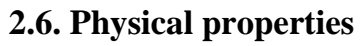

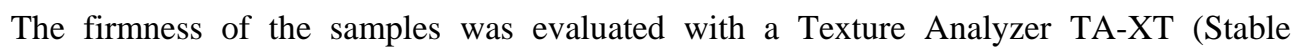

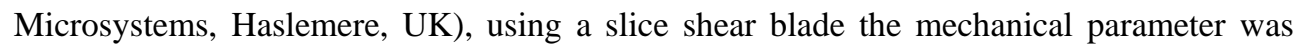

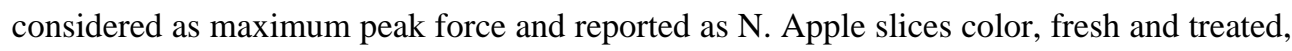

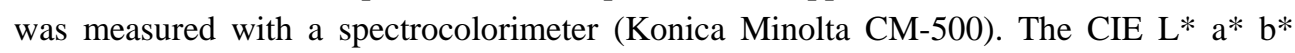


coordinates used a $\mathrm{D}_{65}$ illuminant and $10^{\circ}$ observer as a system reference. The color was measured in triplicate.

\section{Results and Discussion}

\subsection{Total phenolic content (TPC)}

The phenolic content of the treated apple samples is expressed in mg gallic acid equivalent (GAE) in $100 \mathrm{~g}$ of dry matter. As Fig. 1 shows the apples treated with PVOD/OH at $30{ }^{\circ} \mathrm{C}$ had higher retention of TPC throughout the processing time $(180 \mathrm{~min})$, followed by $\mathrm{PVOD} / \mathrm{OH} 50{ }^{\circ} \mathrm{C}$; the samples with the lowest phenolic retention were the PVOD $40{ }^{\circ} \mathrm{C}$ $\mathrm{OD} / \mathrm{OH} 50^{\circ} \mathrm{C}$.

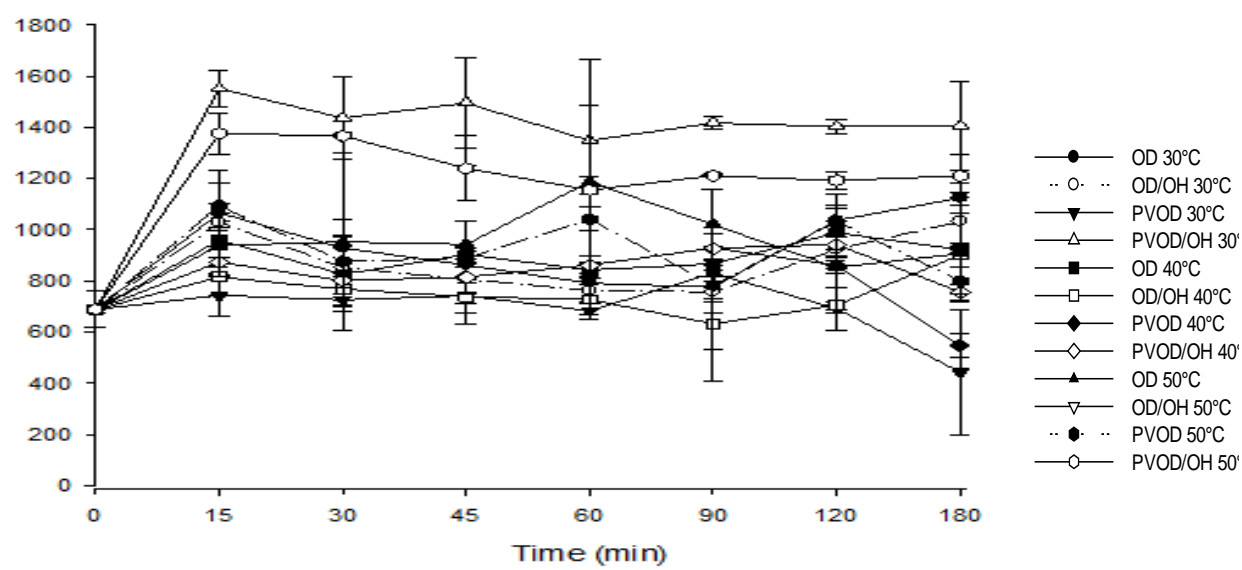

Fig. 1 Total phenolic content (TPC) kinetics of osmodehydrated apple using cryoconcentrated pomegranate juice for $180 \mathrm{~min}$. OD: osmotic dehydration at atmospheric pressure, PVOD: osmotic dehydration with vacuum pulsed vacuum, $\mathrm{OH}$ : ohmic heating $(\mathrm{OD} / \mathrm{OH}$ and $\mathrm{PVOD} / \mathrm{OH})$ at $6.66 \mathrm{~V} / \mathrm{cm}$

Furthermore, the total phenolic content decreases for all treated samples after $30 \mathrm{~min}$ of the process except $\mathrm{PVOD} / \mathrm{OH} 30^{\circ} \mathrm{C}$; this may be due to the kind of treatment, temperature and time. Also after de processing time most of the treatments retained at least the same amount of TPC as in time 0, except PVOD $40^{\circ} \mathrm{C}$, such finding differs with (10); in which the fresh sample had a significant difference in the TPC compare to the treated. 


\subsection{Compositional changes and water activity}

Table 1 shows the compositional changes between the fresh and different treatments of osmodehydration after $180 \mathrm{~min}$ of processing. According to previous findings, osmotic dehydration with concentrated juice is more significant compared to osmotic dehydration with sucrose (13). The combination of PVOD/OH 40 and $50^{\circ} \mathrm{C}$, and PVOD $30^{\circ} \mathrm{C}$ had the highest solute gain had more significant water loss and solid gain, due to the diffusion and convection forces, both which facilitate the mass transfer process. Application of pulsed vacuum eases the osmotic agent into the matrix pores and facilitates the water loss and has a beneficial effect on the kinetics, reaching equilibrium easily (10). Also, the combination of $\mathrm{OD} / \mathrm{OH}$ encouraged more substantial concentration levels in samples than OD.

Table 1. Composition parameters of fresh and processed samples (processing time: $180 \mathrm{~min}$ ) water mass fraction $\left(X_{w}\right)$, soluble solids mass fraction $\left(X_{s s}\right)$, water loss $\left(\Delta M^{w} t\right)$, solid gain $\left(\Delta M_{t}^{s s_{t}}\right)$ and water activity $\left(a_{w}\right)$.

\begin{tabular}{|c|c|c|c|c|c|}
\hline Treatments & $\mathbf{X}_{\mathbf{w}}$ & $\mathbf{X}_{\mathrm{ss}}$ & $\Delta \mathbf{M}^{\mathbf{w}}{ }_{t}$ & $\Delta \mathbf{M}^{\mathrm{ss}}$ & $\mathbf{a}_{\mathrm{w}}$ \\
\hline Fresh & $0.85 \pm 0.01^{\mathrm{g}}$ & $0.22 \pm 0.02^{\mathrm{a}}$ & - & - & $0.98 \pm 0.09^{g}$ \\
\hline OD $30^{\circ} \mathrm{C}$ & $0.58 \pm 0.01^{\mathrm{f}}$ & $0.33 \pm 0.02^{\mathrm{b}}$ & $-0.32 \pm 0.04^{c}$ & $0.63 \pm 0.12^{\mathrm{d}}$ & $0.91 \pm 0.01^{\mathrm{d}, \mathrm{e}}$ \\
\hline $\mathrm{OD} / \mathrm{OH} 30^{\circ} \mathrm{C}$ & $0.56 \pm 0.01^{\mathrm{d}, \mathrm{e}, \mathrm{f}}$ & $0.77 \pm 0.02^{\mathrm{d}}$ & $-0.85 \pm 0.03^{c}$ & $2.14 \pm 0.15^{\mathrm{a}}$ & $0.91 \pm 0.01^{\mathrm{e}, \mathrm{f}}$ \\
\hline PVOD $30^{\circ} \mathrm{C}$ & $0.56 \pm 0.01^{\mathrm{d}, \mathrm{e}, \mathrm{f}}$ & $0.90 \pm 0.12^{\mathrm{e}}$ & $-0.27 \pm 0.01^{\mathrm{a}}$ & $0.45 \pm 0.08^{\mathrm{d}, \mathrm{e}}$ & $0.91 \pm 0.01^{\mathrm{c,d}}$ \\
\hline $\mathrm{PVOD} / \mathrm{OH} 30^{\circ} \mathrm{C}$ & $0.55 \pm 0.05^{\mathrm{d}, \mathrm{e}, \mathrm{f}}$ & $0.72 \pm 0.03^{\mathrm{d}}$ & $-0.27 \pm 0.01^{\mathrm{a}}$ & $1.88 \pm 0.08^{\mathrm{a}, \mathrm{b}}$ & $0.92 \pm 0.01^{\mathrm{f}}$ \\
\hline $\mathrm{OD} 40^{\circ} \mathrm{C}$ & $0.57 \pm 0.01^{\mathrm{e}, \mathrm{f}}$ & $0.47 \pm 0.23^{\mathrm{c}}$ & $-0.66 \pm 0.08^{b}$ & $1.50 \pm 0.06^{b, c}$ & $0.91 \pm 0.01^{\mathrm{e}, \mathrm{f}}$ \\
\hline $\mathrm{OD} / \mathrm{OH} 40^{\circ} \mathrm{C}$ & $0.52 \pm 0.01^{\mathrm{d}, \mathrm{c}, \mathrm{d}}$ & $0.79 \pm 0.04^{\mathrm{d}}$ & $-0.66 \pm 0.05^{\mathrm{b}}$ & $1.35 \pm 0.81^{\mathrm{c}}$ & $0.90 \pm 0.01^{\mathrm{c}, \mathrm{d}}$ \\
\hline PVOD $40^{\circ} \mathrm{C}$ & $0.54 \pm 0.01^{\mathrm{b}, \mathrm{c}, \mathrm{d}}$ & $0.82 \pm 0.03^{\mathrm{d}, \mathrm{e}}$ & $-0.36 \pm 0.16^{\mathrm{a}}$ & $0.51 \pm 0.03^{\mathrm{d}, \mathrm{e}}$ & $0.91 \pm 0.01^{\mathrm{d}, \mathrm{e}, \mathrm{f}}$ \\
\hline $\mathrm{PVOD} / \mathrm{OH} 40^{\circ} \mathrm{C}$ & $0.51 \pm 0.03^{\mathrm{a}, \mathrm{b}, \mathrm{c}}$ & $0.78 \pm 0.01^{\mathrm{d}}$ & $-0.31 \pm 0.24^{\mathrm{a}}$ & $1.27 \pm 0.22^{\mathrm{d}, \mathrm{e}}$ & $0.90 \pm 0.01^{\mathrm{b}, \mathrm{c}}$ \\
\hline $\mathrm{OD} 50^{\circ} \mathrm{C}$ & $0.57 \pm 0.01^{\mathrm{e}, \mathrm{f}}$ & $0.76 \pm 0.02^{\mathrm{d}}$ & $-1.15 \pm 0.01^{\mathrm{d}}$ & $2.08 \pm 0.45^{\mathrm{a}, \mathrm{b}}$ & $0.92 \pm 0.01^{\mathrm{f}}$ \\
\hline $\mathrm{OD} / \mathrm{OH} 50^{\circ} \mathrm{C}$ & $0.47 \pm 0.02^{\mathrm{a}, \mathrm{b}}$ & $0.80 \pm 0.06^{\mathrm{d}, \mathrm{e}}$ & $-0.33 \pm 0.09^{\mathrm{a}}$ & $0.51 \pm 0.07^{\mathrm{d}, \mathrm{e}}$ & $0.89 \pm 0.01^{\mathrm{b}}$ \\
\hline PVOD $50^{\circ} \mathrm{C}$ & $0.52 \pm 0.01^{\mathrm{c}, \mathrm{d}, \mathrm{e}}$ & $0.79 \pm 0.02^{\mathrm{d}, \mathrm{e}}$ & $-0.28 \pm 0.07^{\mathrm{a}}$ & $0.52 \pm 0.10^{\mathrm{d}}$ & $0.92 \pm 0.01^{\mathrm{e}, \mathrm{f}}$ \\
\hline $\mathrm{PVOD} / \mathrm{OH} 50^{\circ} \mathrm{C}$ & $0.49 \pm 0.01^{\mathrm{a}, \mathrm{b}}$ & $0.81 \pm 0.01^{\mathrm{d}, \mathrm{e}}$ & $-0.35 \pm 0.01^{\mathrm{a}}$ & $0.65 \pm 0.03^{\mathrm{d}}$ & $0.87 \pm 0.00^{\mathrm{a}}$ \\
\hline
\end{tabular}

In this case, the mass transfer in PVOD and PVOD/OH in comparison to the OD is due to the unsteadiness of particles in the juice. Likewise, inadequate dissemination of the components may occur when gradients pressure in the vegetable tissue provoke the irregular flow of the osmotic agent through the structure and consequently accumulate bioactive components in some areas (14); making the mass transfer harder in OD.The most significant water activity reduction was in PVOD/OH $50{ }^{\circ} \mathrm{C}$, followed by $\mathrm{OD} / \mathrm{OH} 50^{\circ} \mathrm{C}$ in contrast to the fresh sample. This difference is attributed to temperature, $\mathrm{pH}$, and 
electroporation which promote the gain of freeze concentrated pomegranate juice and water loss (15).

\subsection{Changes in physical properties}

Table 2 shows the values obtained for the fresh and treated apple, the hue angle (h*ab), chrome $\left(\mathrm{C}^{*} \mathrm{ab}\right)$ and change in color $(\Delta \mathrm{E})$. Previous studies have demonstrated $\mathrm{L}$ increases with the osmotic treatments (15). However, samples with the combination of PVOD and $\mathrm{PVOD} / \mathrm{OH}$ have reduced $\mathrm{L}$, due to the concentration of anthocyanins from the pomegranate juice, this same effect reported by (9) treated sample had lower $L$ than the fresh one. The $\Delta \mathrm{E}$ was higher in the same treatments as the $\mathrm{L}$, this due to the content of anthocyanin pigments present in the cryoconcentrated pomegranate juice. The firmness values acquired from the mechanical test (Table 2). A sample of PVOD $30^{\circ} \mathrm{C}$ had the firmness highest value which indicates a higher resistance. Fresh sample differs significantly from the samples treated at $50{ }^{\circ} \mathrm{C}$. Although, values from treatments at $40{ }^{\circ} \mathrm{C}$ had no difference with the fresh sample, as well as $\mathrm{OD} / \mathrm{OH}$ and PVOD at $30{ }^{\circ} \mathrm{C}$.

Table 2. Firmness and color determination in fresh and treated apples with three temperatures $\left(30 \mathrm{C}, 40 \mathrm{C}, 50^{\circ} \mathrm{C}\right)$.

\begin{tabular}{|c|c|c|c|c|c|}
\hline \multirow{2}{*}{ Treatments } & \multirow{2}{*}{$\begin{array}{l}\text { Firmness } \\
\text { (N) }\end{array}$} & \multicolumn{4}{|l|}{ Color } \\
\hline & & $L^{*}$ & $C^{*} a b$ & $h^{*} a b$ & $\Delta \boldsymbol{E}$ \\
\hline Fresh & $12.75 \pm 3.53^{c}$ & $64.38 \pm 5.53^{c}$ & $16.80 \pm 3.16^{\mathrm{d}}$ & $96.48 \pm 3.06^{\mathrm{a}}$ & --- \\
\hline OD $30^{\circ} \mathrm{C}$ & $26.34 \pm 3.83^{\mathrm{d}, \mathrm{e}}$ & $29.27 \pm 2.12^{\mathrm{b}}$ & $30.63 \pm 2.14^{\mathrm{f}}$ & $199.88 \pm 0.69^{g}$ & $45.14 \pm 2.97^{d}$ \\
\hline $\mathrm{OD} / \mathrm{OH} 30^{\circ} \mathrm{C}$ & $15.99 \pm 1.05^{c}$ & $26.43 \pm 1.79^{b}$ & $23.96 \pm 5.48^{\mathrm{e}}$ & $198.31 \pm 2.10^{\mathrm{f}, \mathrm{g}}$ & $45.80 \pm 3.54^{\mathrm{d}}$ \\
\hline PVOD $30^{\circ} \mathrm{C}$ & $29.35 \pm 4.19^{\mathrm{e}}$ & $22.25 \pm 3.19^{\mathrm{a}, \mathrm{b}}$ & $15.58 \pm 7.28^{\mathrm{c}, \mathrm{d}}$ & $194.91 \pm 3.38^{\mathrm{e}, \mathrm{f}}$ & $39.85 \pm 1.43^{b, c}$ \\
\hline $\mathrm{PVOD} / \mathrm{OH} 30^{\circ} \mathrm{C}$ & $10.87 \pm 2.88^{\mathrm{b}, \mathrm{c}}$ & $20.57 \pm 1.18^{\mathrm{a}, \mathrm{b}}$ & $3.84 \pm 0.49^{\mathrm{a}}$ & $178.17 \pm 2.80^{\mathrm{b}}$ & $48.91 \pm 4.78^{\mathrm{e}, \mathrm{f}}$ \\
\hline $\mathrm{OD} 40^{\circ} \mathrm{C}$ & $14.61 \pm 2.70^{\mathrm{b}, \mathrm{c}}$ & $29.27 \pm 2.12^{\mathrm{a}, \mathrm{b}}$ & $30.63 \pm 2.14^{\mathrm{f}}$ & $199.88 \pm 0.69^{g}$ & $47.89 \pm 0.60^{\mathrm{d}, \mathrm{e}}$ \\
\hline $\mathrm{OD} / \mathrm{OH} 40^{\circ} \mathrm{C}$ & $9.34 \pm 0.61^{\mathrm{b}, \mathrm{c}}$ & $24.70 \pm 1.81^{\mathrm{a}, \mathrm{b}}$ & $17.47 \pm 3.30^{\mathrm{d}}$ & $197.50 \pm 1.09^{\mathrm{f}, \mathrm{g}}$ & $42.03 \pm 2.63^{c}$ \\
\hline PVOD $40^{\circ} \mathrm{C}$ & $17.34 \pm 2.97^{\mathrm{c}, \mathrm{d}}$ & $21.63 \pm 1.53^{\mathrm{a}, \mathrm{b}}$ & $9.75 \pm 3.12^{\mathrm{b}}$ & $191.83 \pm 0.31^{\mathrm{d}}$ & $45.72 \pm 0.76^{\mathrm{d}}$ \\
\hline $\mathrm{PVOD} / \mathrm{OH} 40^{\circ} \mathrm{C}$ & $8.57 \pm 1.88^{\mathrm{b}, \mathrm{c}}$ & $20.62 \pm 0.51^{\mathrm{a}}$ & $3.45 \pm 0.63^{\mathrm{a}}$ & $183.74 \pm 1.49^{c}$ & $51.82 \pm 1.97^{\mathrm{f}, \mathrm{g}}$ \\
\hline OD $50^{\circ} \mathrm{C}$ & $2.88 \pm 1.57^{\mathrm{a}}$ & $23.06 \pm 1.14^{\mathrm{a}}$ & $13.97 \pm 3.68^{b, c}$ & $197.59 \pm 1.53^{\mathrm{f}, \mathrm{g}}$ & $50.65 \pm 1.91^{\mathrm{e}, \mathrm{f}}$ \\
\hline $\mathrm{OD} / \mathrm{OH} 50^{\circ} \mathrm{C}$ & $2.70 \pm 0.17^{\mathrm{a}}$ & $22.96 \pm 2.03^{\mathrm{a}}$ & $10.99 \pm 1.19^{\mathrm{b}, \mathrm{c}}$ & $196.69 \pm 0.15^{\mathrm{f}, \mathrm{g}}$ & $38.25 \pm 2.00^{\mathrm{b}}$ \\
\hline $\begin{array}{l}\text { PVOD } 50^{\circ} \mathrm{C} \\
\text { PVOD } / \mathrm{OH} 50^{\circ} \mathrm{C}\end{array}$ & $\begin{array}{l}5.34 \pm 1.75^{\mathrm{b}} \\
6.27 \pm 0.87^{\mathrm{b}}\end{array}$ & $\begin{array}{l}21.01 \pm 0.16^{\mathrm{a}} \\
20.67 \pm 0.72^{\mathrm{a}}\end{array}$ & $\begin{array}{l}3.92 \pm 1.08^{\mathrm{a}} \\
3.06 \pm 0.96^{\mathrm{a}}\end{array}$ & $\begin{array}{l}188.74 \pm 2.81^{\mathrm{d}} \\
189.30 \pm 2.62^{\mathrm{d}}\end{array}$ & $\begin{array}{l}51.69 \pm 1.99^{f} \\
54.73 \pm 2.47^{f}\end{array}$ \\
\hline
\end{tabular}

Different letters $\left({ }^{\mathrm{a}, . \mathrm{g}}\right)$ in each column indicate significant differences at $p \leq 0.05$, according to a LSD test. 


\section{Conclusion}

The combination of pulsed vacuum and ohmic heating in the osmodehydration of apple slices at $30^{\circ} \mathrm{C}$ affected the retention of total phenolic content positively during processing time (180 min). Osmotic dehydration combined with pulsed vacuum and ohmic heating at 50 and $40{ }^{\circ} \mathrm{C}$ intensifies the solid gain and water loss due to the diffusion and convection forces which accelerated the mass transfer process. $\mathrm{PVOD} / \mathrm{OH}$ and $\mathrm{OD} / \mathrm{OH} 50^{\circ} \mathrm{C}$ had the most significant water activity mainly cause by the electroporation and temperature. The changes in color were significant in $\mathrm{C}^{*} \mathrm{ab}$ (chrome) in $\mathrm{L}^{*}$ (lightness), and values in treated apple slices with PVOD and PVOD/OH due to retention of anthocyanins from the freeze concentrated pomegranate juice. The highest firmness was observed in a sample of PVOD $30{ }^{\circ} \mathrm{C}$. Therefore, our results suggest that $\mathrm{PVOD} / \mathrm{OH}$ process at $50{ }^{\circ} \mathrm{C}$ by $180 \mathrm{~min}$ is the optimal treatment for osmodehydrated apples with freeze concentrated pomegranate juice.

\section{Acknowledgements}

Jorge Moreno is thankful for the financial aid provided by CONICYT through project FONDECYT 1160761.

\section{References}

[1] Stelzer, I., Zelzer, S., Raggam, R. B., Prüller, F., Truschnig-Wilders, M., Meinitzer, A. \& Reeves, G.. Link between leptin and interleukin-6 levels in the initial phase of obesity-related inflammation. Translational Research, 2012, 159(2), 118-124.

[2] Moreno, J., Zúñiga, P., Jara, E., Gianelli, M., Mella, K., \& Petzold, G. (2017). Ohmic Heating and Bioactive Compounds. In J. Moreno, Innovative Processing Technologies for Foods with Bioactive Compounds. Boca Raton, FL., United States of America: CRC Press, 2017, págs. 31-60.

[3] Mirdehghan, S. H., \& Rahemi, M.. Seasonal changes of mineral nutrients and phenolics in pomegranate (Punica granatum L.) fruit. Scientia Horticulturae, 2007, 111(2), 120-127.

[4] Fuster-Muñoz, E., Roche, E., Funes, L., Martínez-Peinado, P., Sempere, J. M., \& Vicente-Salar, N. Effects of pomegranate juice in circulating parameters, cytokines, and oxidative stress markers in endurance-based athletes: A randomized controlled trial. Nutrition, 2016, 32(5), 539-545.

[5] Petzold, G., Orellana, P., Moreno, J., Junod, J., \& Bugeño, G. (2017). Freeze concentration as a technique to protect valuable heat-labile components of foods. In J. Moreno, Innovative Processing Technologies for Foods with Bioactive Compounds Boca Raton, FL., United States of America: CRC Press, 2017, págs. 31-60. 


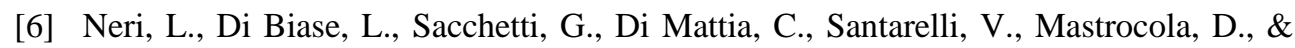

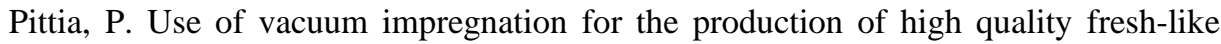

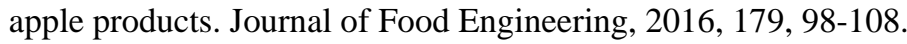

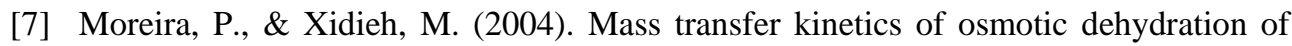

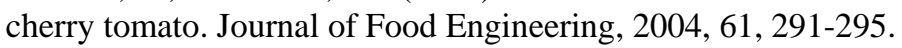

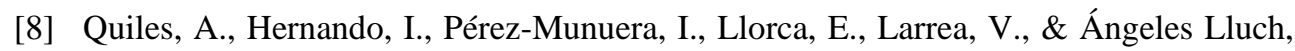

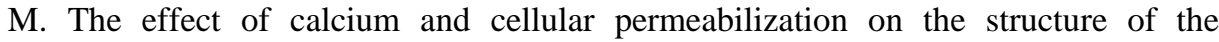

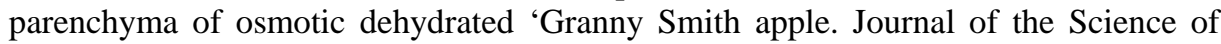

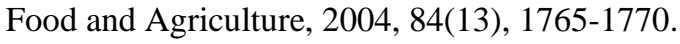

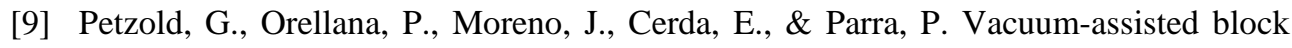

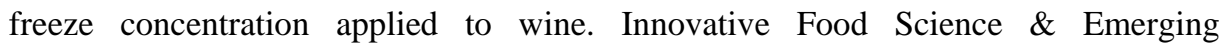

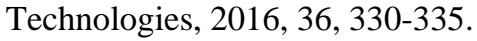

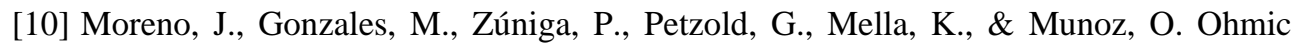

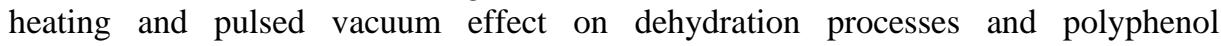

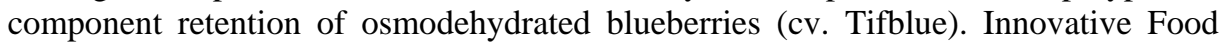

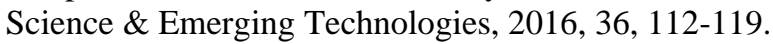

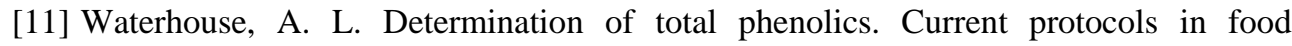

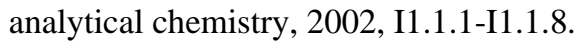

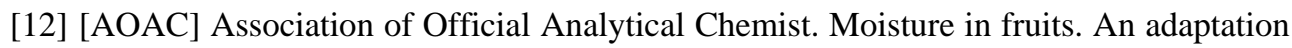

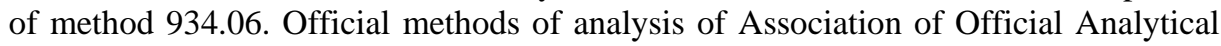

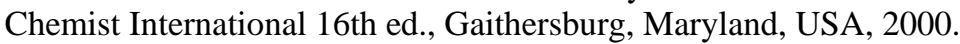

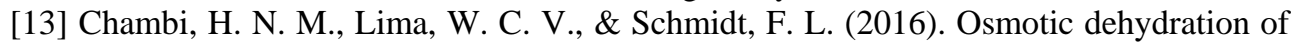

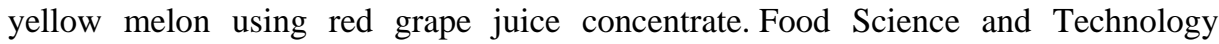

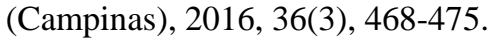

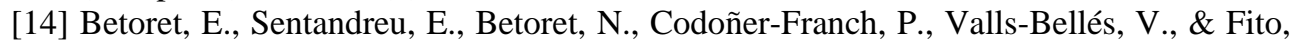

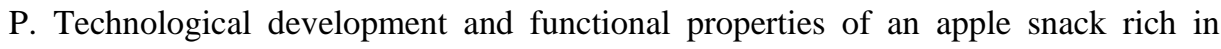

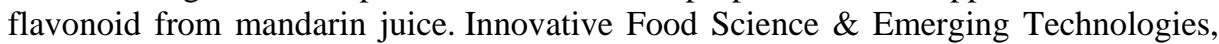

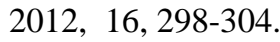

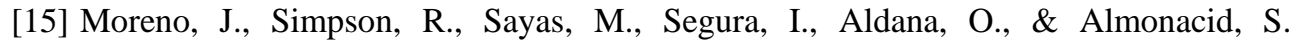

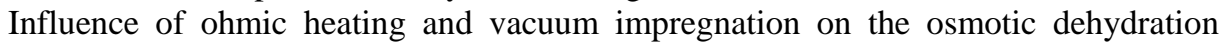

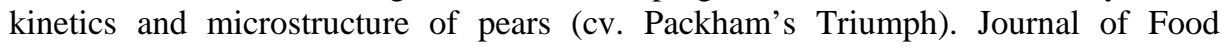

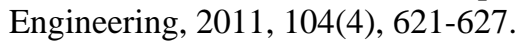

